\title{
Authentication of Three Endemic Species of the Caryophyllaceae from Sinai Peninsula Using DNA Barcoding
}

\author{
A.S. Fouad ${ }^{(1) *}$, R.M. Hafez ${ }^{(1)}$, H.A. Hosni ${ }^{(2)}$ \\ (1)Botany and Microbiology Department, Faculty of Science, Cairo University, Giza \\ 12613, Egypt; (2) The Herbarium, Botany and Microbiology Department, Faculty of \\ Science, Cairo University, Giza 12613, Egypt.
}

\begin{abstract}
$\mathbf{T}$ THE CARYOPHYLLACEAE are one of the most represented families with endemic species in Sinai Peninsula, Egypt. rbcl-based DNA barcoding sequences for three species of Caryophyllaceae endemic to Sinai Peninsula (Bufonia multiceps, Silene leucophylla and $S$. oreosinaica) were developed for the first time. BLASTN for these sequences reflected $100 \%$ Caryophyllaceae hits for rbcl sequences. Phylogenetic tree constructed using the the newly developed and mined sequences showed an ambiguous classification at both generic and tribal levels. Results reflected that such species were introduced into Sinai Peninsula through two colonization events. The first introduced $S$. leucophylla while the second introduced a common ancestor for the remaining two species.
\end{abstract}

Keywords: Endemics, Caryophyllaceae, rbcl, Bufonia multiceps, Silene leucophylla, Silene oreosinaica, Sinai.

\section{Introduction}

The term genres endemiques (endemic taxa) was coined by De Candolle (1820) to describe species restricted to a particular geographic region. However, the term was not commonly employed before the beginnings of the last century where it appeared regularly in an innumerable scientific publications (Hobohm \& Tucker, 2014). Aiming to explain endemism, two different models are accepted. The refuge model (Gankin \& Major, 1964) suggests that endemic plants are stresstolerant taxa confined to stressful environment where interspecific competition is minimized (Meyer et al., 1992). On the other hand, the specialist model suggests adaptation of endemics to the habitats they occupy (Meyer, 1986), but not other habitats (Baskauf \& Eickmeier, 1994; Wilson, 1994 and Caley \& Munday, 2003).

Today, endemism receives increasing attention and is used for identification of biodiversity hotspots (Orme et al., 2005 and Lamoreux et al., 2006). Firstly, endemics are potentially threatened due to their restricted distribution (Linder, 1995 and Gaston \& Blackburn, 1996). Secondly, limited resources hinder humans to protect all species (Myers et al., 2000). Consequently, centers of endemism are very important for conservation planning due to presence of large numbers of endemics in a relatively small land area (Stattersfield et al., 1998 and Myers et al., 2000).

Sinai Peninsula is a major phytogeographical region in Egypt hosting 30 of the 37 taxa believed to be endemic to Egypt in only $6.1 \%$ of the area of Egypt (Hosni et al., 2013). It is a bridge between Africa and Asia and hosts flora influenced by both continental masses. Saint Catherine area encloses most of the mountainous area of South Sinai; it occupies about $4350 \mathrm{~km}^{2}$ including the country's highest mountain, Mount Catherine (2641m, asl). This area is of great biological interest: it contains about $30 \%$ of Egypt's endemic taxa (El Hadidi, 2000). Many of such taxa are important components of the Egyptian genetic, food, heritage, and medicinal capabilities (Carlquist, 1974; Strid, 1986 and Shehata \& Kamel, 2007). Caryophyllaceae are one of the most represented families among endemic species in Sinai Peninsula. It contains the most represented genus, Silene including six endemic taxa (Hosni et al., 2013).

"Corresponding author email: ahmedsfouad@yahoo.com

DOI: 10.21608/ejbo.2019.5932.1241

Edited by: Prof. Dr. Adel El-Gazzar, Faculty of Science, El-Arish University, El-Arish, N. Sinai, Egypt.

(C)2019 National Information and Documentation Center (NIDOC) 
Authentication of endemic species is an important base for evolutionary and phytogeographic studies as well as for determination of conservation priorities (Ungricht, 2004; Ferreira \& Boldrini, 2011 and Bacchetta et al., 2012). DNA barcoding is an authentic cost-effective rapid tool for species recognition employing DNA sequences as species internal tags (Hebert et al., 2003 and Hebert \& Gregory, 2005). Due to its high amplification success rate, rbcl (ribulose bisphosphate carboxylase large subunit) gene is the most published plastid barcode (Newmaster et al., 2006 and Kang et al., 2017). Unlike morphological identification, DNA barcoding is free from subjective biases and does not require taxonomic experience (Bafeel et al., 2012). In addition, molecular techniques can be used even with unrecognizable plant parts that enable tracing of endangered species in illegal trade affecting endemic as well as non-endemic species (Hobohm \& Tucker, 2014).

Therefore, the aim of this investigation is to authenticate three endemic species to Sinai Peninsula: Bufonia multiceps, Silene leucophylla and $S$. oreosinaica (Caryophyllaceae) using rbclbased DNA barcoding.

\section{Materials and Methods}

Leaf samples (20mg each) for each species were collected from three herbarium specimens kept in Cairo University Herbarium (CAI) and ground using a mortar and pestle with aid of liquid nitrogen to produce fine powder. Extraction of DNA was carried out using a Qiagen DNeasy kit (Valencia, California, USA) according to manufacturer's protocol with some modifications for herbarium samples. The AP1 buffer was fortified with dithiothreitol (Melford Laboratories, UK) and Proteinase K(Sigma) at 0.12 and 0.04 $\mathrm{mg} / \mathrm{ml}$, respectively (de Vere et al., 2012). rbcl sequences were amplified in $50 \mu 1$ reaction mixture containing $25 \mu \mathrm{l}$ PCR Master Mix (Bioline), 20$50 \mathrm{ng}$ genomic DNA and $1 \mu \mathrm{l}$ of each specific primer (5'-ATGTCACCACAAACAGAAAC-3' and 5'-TCGCATGTACCTGCAGTAGC-3'). The amplification protocol was $95^{\circ} \mathrm{C}$ for $2 \mathrm{~min}$ followed by 34 cycles of $94^{\circ} \mathrm{C}$ for $1 \mathrm{~min}, 55^{\circ} \mathrm{C}$ for $30 \mathrm{sec}$ and $72^{\circ} \mathrm{C}$ for $1 \mathrm{~min}$, then final extension for $7 \mathrm{~min}$ at $72^{\circ} \mathrm{C}$ (CBOL Plant Working Group, 2009). PCR products were visualized under UV light on $1.5 \%(\mathrm{~m} / \mathrm{v})$ agarose gel.
After purification step using the QIAquick PCR Purification Kit (Qiagen, Hilden, Germany), amplification products were sequenced using Big-dye terminator chemistry in 3130xl Genetic Analyzer (Life Technologies, California, USA) by following the standard manufacturer's protocol. The resulted rbcl sequences were submitted to the GenBank database under accession numbers MH899451, MH899453 and MK040533 for Bufonia multiceps, Silene leucophylla and $S$. oreosinaica, respectively. These sequences were blasted against the available ones from GenBank data base; the resulted sequences were used to construct a phylogenetic tree (using the taxonomically distant species Nicotiana tabacum as outgroup for best resolution) and pairwise distances calculations using Maximum Likelihood (ML) method and Clustal W in MEGA v. 6 (Tamura et al., 2013) based on the Kimura 2-parameter model (Kimura, 1980) with gamma distribution. Significance was assessed using 1000 bootstrap replications (Felsenstein, 1985).

\section{Results and Discussion}

PCR amplifications for rbcl regions resulted in 750 bp band in each species (Fig. 1 Suppl.). Generally, a Product of $650-850 \mathrm{bp}$ resulted following amplification of such region (Kress et al., 2005 and Bafeel et al., 2011). Sequencing for rbcl regions of Bufonia multiceps, Silene leucophylla and S. oreosinaica resulted in 471, 561 and 522 bp sequences, respectively (Fig. 2 Suppl.). BLASTN for these sequences reflected $100 \%$ Caryophyllaceae hits for rbcl sequences of 484-1408 bp length.

Sequences mined from GenBank included eight tribes represented by 20 genera (Fig. 1), with overall mean interspecific K2P distance of 0.025 and pairwise distances ranged from 0.00 to 0.102 . Among mined sequences, estimates of evolutionary divergence showed that Psammophiliella muralis, Sagina nodosa and $S$. procumbens were the closest taxa for Bufonia multiceps with 0.028 intraspecific K2P distance (Table 1). Smaller distance (0.002) was recorded between Silene leucophylla and its closest species; Atocion rupestre, Silene pygmaea, S. acaulis, $S$. aprica and $S$. antirrhina. In contrast, Colobanthus subulatus, Sagina nodosa and S. procumbens (belonging to Saginae) were the closest species to the Sileneae taxon, Silene oreosinaica, with intraspecific K2P distance of 0.82 . 


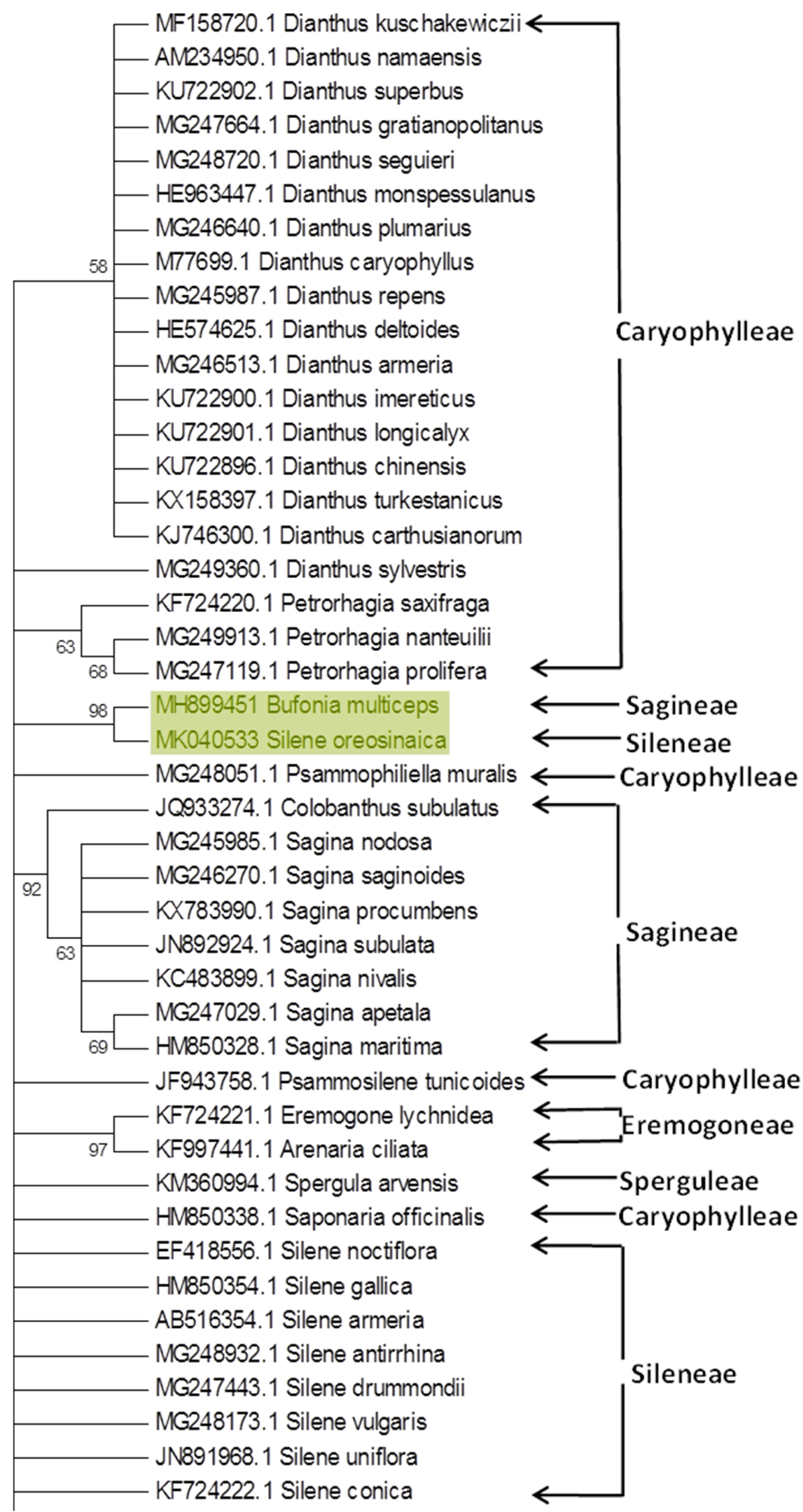

Egypt. J. Bot. 59 , No.2 (2019) 


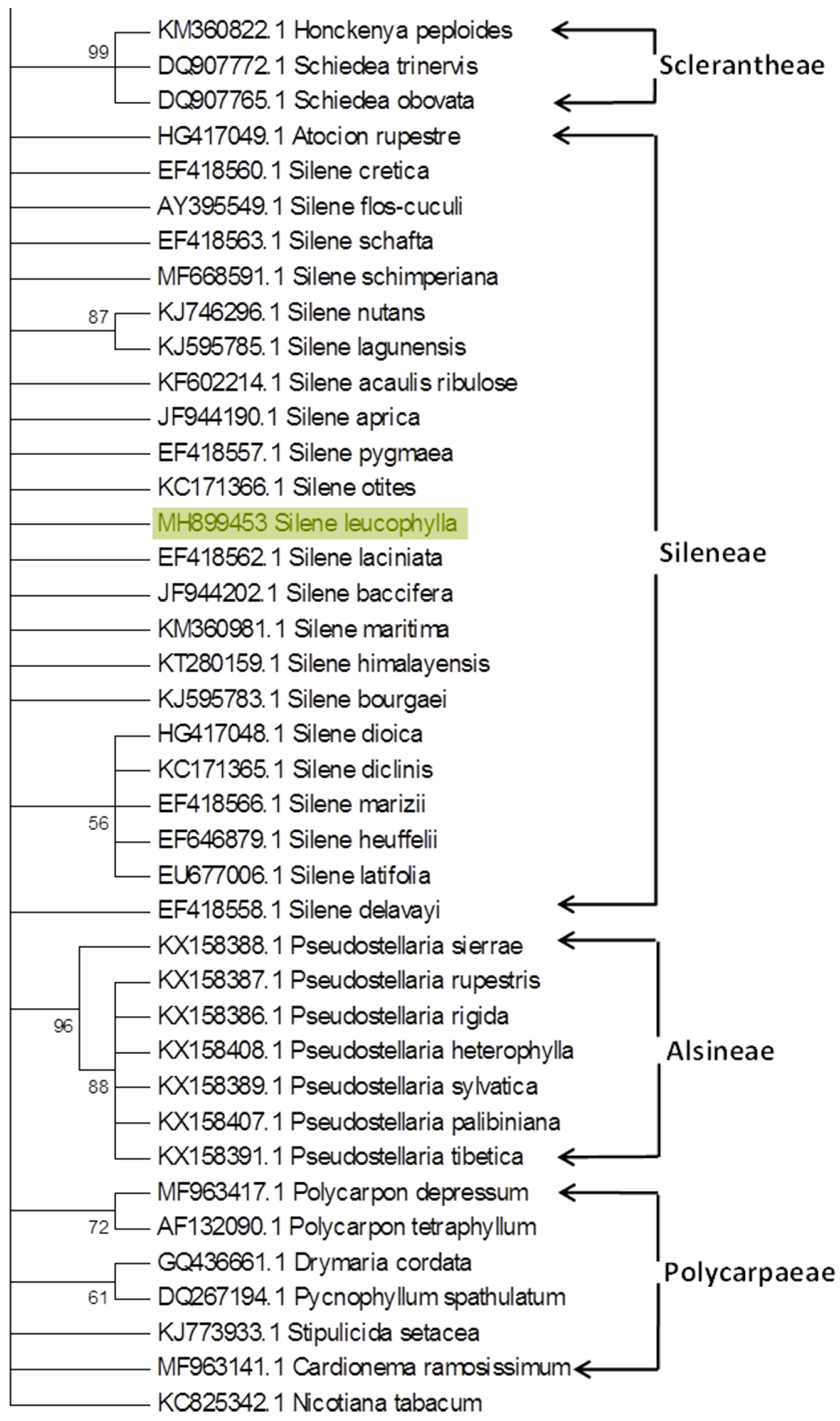

Fig. 1. Phylogenetic tree using Maximum Likelihood method based on Kimura 2-parameter model for rbcl sequences. Bootstrap values based on 1000 replications are listed as percentages at branching points [Tribes following Stevens PF (2001)]. 
TABLE 1. Estimates of evolutionary divergence between rbcl sequences in B. multiceps, $S$. leucophylla and $S$. oreosinaica and mined sequences based on the K2P model.

\begin{tabular}{|c|c|c|c|}
\hline Mined Sequence & Bufonia multiceps & Silene leucophylla & Silene oreosinaica \\
\hline Bufonia multiceps & & 0.036 & 0.060 \\
\hline Silene leucophylla & 0.036 & & 0.093 \\
\hline Silene oreosinaica & 0.060 & 0.093 & \\
\hline Dianthus repens & 0.033 & 0.023 & 0.093 \\
\hline Dianthus deltoides & 0.033 & 0.023 & 0.093 \\
\hline Dianthus imereticus & 0.033 & 0.023 & 0.096 \\
\hline Dianthus gratianopolitanus & 0.036 & 0.025 & 0.093 \\
\hline Dianthus carthusianorum & 0.033 & 0.023 & 0.093 \\
\hline Dianthus monspessulanus & 0.033 & 0.023 & 0.093 \\
\hline Dianthus turkestanicus & 0.036 & 0.025 & 0.093 \\
\hline Dianthus superbus & 0.033 & 0.023 & 0.093 \\
\hline Dianthus plumarius & 0.033 & 0.023 & 0.093 \\
\hline Dianthus caryophyllus & 0.033 & 0.023 & 0.093 \\
\hline Dianthus kuschakewiczii & 0.036 & 0.025 & 0.093 \\
\hline Dianthus chinensis & 0.033 & 0.023 & 0.093 \\
\hline Dianthus seguieri & 0.033 & 0.023 & 0.093 \\
\hline Dianthus armeria & 0.033 & 0.023 & 0.093 \\
\hline Dianthus longicalyx & 0.033 & 0.023 & 0.096 \\
\hline Dianthus namaensis & 0.038 & 0.028 & 0.096 \\
\hline Dianthus sylvestris & 0.036 & 0.025 & 0.088 \\
\hline Psammophiliella muralis & 0.028 & 0.023 & 0.093 \\
\hline Petrorhagia saxifraga & 0.033 & 0.023 & 0.090 \\
\hline Petrorhagia nanteuilii & 0.030 & 0.020 & 0.090 \\
\hline Petrorhagia prolifera & 0.030 & 0.020 & 0.099 \\
\hline Honckenya peploides & 0.046 & 0.025 & 0.102 \\
\hline Schiedea trinervis & 0.046 & 0.025 & 0.102 \\
\hline Schiedea obovata & 0.046 & 0.025 & 0.093 \\
\hline Atocion rupestre & 0.038 & 0.002 & 0.093 \\
\hline Spergula arvensis & 0.041 & 0.028 & 0.096 \\
\hline Saponaria officinalis & 0.041 & 0.030 & 0.090 \\
\hline Eremogone lychnidea & 0.030 & 0.025 & 0.085 \\
\hline Arenaria ciliate & 0.030 & 0.025 & 0.085 \\
\hline Sagina saginoides & 0.031 & 0.025 & 0.085 \\
\hline Sagina nivalis & 0.033 & 0.028 & 0.085 \\
\hline Colobanthus subulatus & 0.033 & 0.028 & 0.082 \\
\hline Sagina nodosa & 0.028 & 0.023 & 0.082 \\
\hline Sagina procumbens & 0.028 & 0.023 & 0.082 \\
\hline Sagina subulata & 0.031 & 0.025 & 0.085 \\
\hline Sagina apetala & 0.031 & 0.025 & 0.085 \\
\hline Sagina maritime & 0.033 & 0.028 & 0.099 \\
\hline Silene nutans & 0.041 & 0.005 & 0.099 \\
\hline Silene lagunensis & 0.041 & 0.005 & 0.093 \\
\hline
\end{tabular}


TABLE 1. Cont.

\begin{tabular}{|c|c|c|c|}
\hline Mined Sequence & Bufonia multiceps & Silene leucophylla & Silene oreosinaica \\
\hline Silene otites & 0.041 & 0.005 & 0.093 \\
\hline Silene pygmaea & 0.038 & 0.002 & 0.093 \\
\hline Silene acaulis & 0.038 & 0.002 & 0.093 \\
\hline Silene aprica & 0.038 & 0.002 & 0.090 \\
\hline Silene schafta & 0.036 & 0.005 & 0.090 \\
\hline Silene schimperiana & 0.036 & 0.005 & 0.087 \\
\hline Silene antirrhina & 0.033 & 0.002 & 0.090 \\
\hline Silene cretica & 0.044 & 0.013 & 0.099 \\
\hline Silene flos-cuculi & 0.046 & 0.015 & 0.102 \\
\hline Silene gallica & 0.041 & 0.015 & 0.096 \\
\hline Silene armeria & 0.041 & 0.010 & 0.093 \\
\hline Silene uniflora & 0.033 & 0.007 & 0.090 \\
\hline Silene vulgaris & 0.036 & 0.005 & 0.093 \\
\hline Silene drummondii & 0.033 & 0.005 & 0.090 \\
\hline Silene laciniata & 0.038 & 0.007 & 0.093 \\
\hline Silene delavayi & 0.041 & 0.010 & 0.096 \\
\hline Silene himalayensis & 0.038 & 0.007 & 0.090 \\
\hline Silene noctiflora & 0.046 & 0.018 & 0.102 \\
\hline Silene maritima & 0.038 & 0.007 & 0.093 \\
\hline Silene bourgaei & 0.036 & 0.005 & 0.093 \\
\hline Silene conica & 0.041 & 0.015 & 0.096 \\
\hline Silene baccifera & 0.041 & 0.010 & 0.093 \\
\hline Silene marizii & 0.041 & 0.010 & 0.096 \\
\hline Silene_dioica & 0.041 & 0.010 & 0.096 \\
\hline Silene diclinis & 0.041 & 0.010 & 0.093 \\
\hline Silene heuffelii & 0.041 & 0.010 & 0.096 \\
\hline Silene latifolia & 0.038 & 0.007 & 0.096 \\
\hline Psammosilene tunicoides & 0.038 & 0.023 & 0.096 \\
\hline Pseudostellaria sierra & 0.044 & 0.033 & 0.102 \\
\hline Pseudostellaria heterophylla & 0.041 & 0.030 & 0.099 \\
\hline Pseudostellaria sylvatica & 0.041 & 0.030 & 0.099 \\
\hline Pseudostellaria palibiniana & 0.041 & 0.030 & 0.099 \\
\hline Pseudostellaria rupestris & 0.041 & 0.030 & 0.099 \\
\hline Pseudostellaria tibetica & 0.041 & 0.030 & 0.099 \\
\hline Pseudostellaria rigida & 0.041 & 0.030 & 0.099 \\
\hline Polycarpon depressum & 0.038 & 0.020 & 0.096 \\
\hline Polycarpon tetraphyllum & 0.036 & 0.018 & 0.096 \\
\hline Drymaria cordata & 0.038 & 0.023 & 0.096 \\
\hline Pycnophyllum spathulatum & 0.036 & 0.020 & 0.096 \\
\hline Stipulicida setacea & 0.038 & 0.023 & 0.096 \\
\hline Cardionema ramosissimum & 0.044 & 0.028 & 0.102 \\
\hline
\end{tabular}

Egypt. J. Bot. 59 , No.2 (2019) 
In phyllogenetic tree (Fig. 1), few Silene species were clustered in 2 clades nested in a grade of the remaining Silene taxa, including Silene leucophylla. The tree showed a generally ambiguous classification at both generic and tribal levels. Silene grade was interrupted with Atocion rupestre (an allied species in Sileneae) and Sclerantheae clade. Similarly, Silene oreosinaica and Bufonia multiceps formed a clade supported with bootstrap value of $98 \%$ nested among Caryophylleae species.

The paraphyly of Silene was recorded using different molecular markers including ITS (Oxelman \& Lide'n, 1995 and Desfeux \& Lejeune, 1996), rps16 (Oxelman et al., 1997), SIX1 and YI (Rautenberg et al., 2008) and matk (Harbaugh et al., 2010). It was also demonstrated by Greenberg \& Donoghue (2011) based on analysis of ITS, trnL-trnF, trnQrps16, trnS-trnfM, ndhF, and matK sequences. However, the authors observed monophyly of Sileneae using combination of the same sequences. Paraphyly was also observed in other genera of Caryophyllaceae including Acanthophyllum (Pirani et al., 2014) and Arenaria (Sadeghian et al., 2015) using ITS and plastid rps16 sequences. It may reflect a complex evolutionary history; probably a combination of substitution rate heterogeneity, star-like phylogenetic patterns, and ancient chloroplast recombination (Orthia et al., 2005 and Erixon \& Oxelman, 2008).

Appearance of S. oreosinaica and B. multiceps as sister species on highly bootstrap-supported clade may be explained in light of the findings of Harbaugh et al. (2010) who recorded Sagineae and Sileneae in 2 sister clades. In addition, using few Sagineae taxa in the present tree (due to the insufficient $\mathrm{rbcl}$ sequences of this tribe in the GenBank database) may be responsible for the clade carrying Silene oreosinaica and Bufonia multiceps. Grouping of Silene spp. with Caryophyllaceae taxa belonging to other genera was also recorded by Smissen et al. (2002). The authors observed grouping of Silene antirhina, Spergularia marina and Scleranthus biflorus in $n d h F$-based tree (Smissen et al., 2002).

Based on the present investigation, $S$. leucophylla, S. oreosinaica and B. multiceps were introduced into Sinai Peninsula through two colonization events. The first introduced $S$. leucophylla while the second introduced a common ancestor for the remaining two species.

\section{Conclusion}

Results of this investigation reflect the potential use of DNA barcoding in documentation of endemic endangered species with some issues concerning assigning to the proper taxonomic position. Such issues may be resolved through comprehensive revision of classical taxonomic attributes and filling gaps in present DNA barcoding databases.

\section{$\underline{\text { References }}$}

Bacchetta, G., Brullo, S., Congiu, A., Fenu, G., Garrido, J.L. and Mattana, E. (2012) A new species of Aquilegia (Ranunculaceae) from Sardinia (Italy). Phytotaxa, 56(1), 59-64.

Bafeel, S.O., Arif, I.A., Bakir, M.A., Khan, H.A., Al Farhan, A.H., Al Homaidan, A.A., Ahamed, A. and Thomas, J. (2011) Comparative evaluation of PCR success with universal primers of maturase $\mathrm{K}$ (matK) and ribulose-1, 5-bisphosphate carboxylase oxygenase large subunit (rbcL) for barcoding of some arid plants. Plant Omics, 4(4), 195-198.

Bafeel, S.O., Arif, I.A., Bakir, M.A., Al Homaidan, A.A., Al Farhan, A.H. and Khan, H.A. (2012) DNA barcoding of arid wild plants using rbcL gene sequences. Genetics and Molecular Research, 11(3), 1934-1941.

Baskauf, C.J. and Eickmeier, W.G. (1994) Comparative ecophysiology of a rare and widespread species of Echincea (Asteraceae). American Journal of Botany, 81(8), 958-964.

Caley, M.J. and Munday, P.L. (2003) Growth trades off with habitat specialization. Proceedings of the Royal Society of London. Series B: Biological Sciences, 270(2), S175-S177.

Carlquist, S. (1974) Island Biology. Columbia Univ. Press, New York.

CBOL Plant Working Group (2009) A DNA barcode for land plants. Proceedings of the National Academy of Sciences of the United States of America, 106(31), 12794-12797.

De Candolle, A.B. (1820) Essai elementaire de geographie botanique. In: "Dictionnaire des Sciences Naturelles", pp 1-64. Vol. (18), Flevrault, Strasbourg.

Desfeux, C. and Lejeune, B. (1996) Systematics of 
Euromediterranean Silene (Caryophyllaceae): Evidence from a phylogenetic analysis using ITS sequences. Sciences de la Vie, 319(4), 351-358.

de Vere, N., Rich, T.C.G., Ford, C.R., Trinder, S.A., Long, C., Moore, C.W., Satterthwaite, D., Davies, H., Allainguillaume, J., Ronca, S., Tatarinova, T., Garbett, H., Walker, K. and Wilkinson, M.J. (2012) DNA barcoding the native flowering plants and conifers of Wales. PLoS ONE, 7(6), e37945.

El Hadidi, M.N. (2000) Geomorphology, climate and phytogeographic affinities. In: "Flora Aegyptiaca", M.N. El Hadidi (Ed.). The Palm Press, Cairo, Egypt.

Erixon, P. and Oxelman, B. (2008) Reticulate or tree-like chloroplast DNA evolution in Sileneae (Caryophyllaceae)? Molecular Phylogenetics and Evolution, 48(1), 313-325.

Felsenstein, J. (1985) Confidence limits on phylogenies: An approach using the bootstrap. Evolution, 39(4), 783-791.

Ferreira, P.M.A. and Boldrini, I.I. (2011) Potential reflection on distinct ecological units in plant endemism categories. Conservation Biology, 25(4), 672-679.

Gankin, R. and Major, J. (1964) Arctostaphylos myrtifolia, its biology and relationship to the problem of endemism. Ecology, 45(4), 792-808.

Gaston, K.J. and Blackburn, T.M. (1996) The spatial distribution of threatened species: Macroscales and New World birds. Proceedings of the Royal Society of London Series B-Biological Sciences, 263(1367), 235-240.

Greenberg, A.K. and Donoghue, M.J. (2011) Molecular systematics and character evolution in Caryophyllaceae. Taxon, 60(6), 1637-1652.

Harbaugh, D.T., Nepokroeff, M., Rabeler, R.K., McNeill, J., Zimmer, E.A. and Wagner, W.L. (2010) A new lineage-based tribal classification of the family Caryophyllaceae. International Journal of Plant Sciences, 171(2), 185-198.

Hebert, P.D.N. (2003) Biological identifications through DNA barcodes. Proceedings of the Royal Society of London B Biological Sciences, 270(1512), 313-321.

Hebert, P.D.N. and Gregory, T.R. (2005) The promise of
DNA barcoding for taxonomy. Systematic Biology, 54(5), 852-859.

Hobohm, C. and Tucker, C.M. (2014) The increasing importance of endemism: responsibility, the media and education. In: "Endemism in Vascular Plants". Plant and Vegetation 3-9, C. Hobohm (Ed.). Springer Netherlands, Netherlands.

Hosni, H., Hosny, A., Shamso, E. and Hamdy, R. (2013) Endemic and near-endemic taxa in the flora of Egypt. Egyptian Journal of Botany, 53, 357-383.

Kang, Y., Deng, Z., Zang, R. and Lon, W. (2017) DNA barcoding analysis and phylogenetic relationships of tree species in tropical cloud forests. Scientific Reports, 7, 12564.

Kimura, M. (1980) A simple method for estimating evolutionary rate of base substitutions through comparative studies of nucleotide sequences Journal of Molecular Evolution, 16(2), 111-120.

Kress, W.J., Wurdack, K.J., Zimmer, E.A., Weigt, L.A. and Janzen, D.H. (2005) Use of DNA barcodes to identify flowering plants. Proceedings of the National Academy of Sciences, 102(23), 8369-8374.

Lamoreux, J.F, Morrison, J.C., Ricketts, T.H., Olson, D.M., Dinerstein, E., McKnight, M.W. and Shugart, H.H. (2006) Global tests of biodiversity concordance and the importance of endemism. Nature, 440(7081), 212-214.

Linder, H.P. (1995) Setting conservation prioritiesthe importance of endemism and phylogeny in the southern African orchid genus Herschelia. Conservation Biology, 9(3), 585-595.

Meyer, S.E. (1986) The ecology of gypsophile endemism in the eastern Mojave Desert. Ecology, 67(5), 13031313.

Meyer, S.E., García-Moya, E. and Lagunes-Espinoza, L.D.C. (1992) Topographic and soil surface effects on gypsophile plant community patterns in central Mexico. Journal of Vegetation Science, 3(3), 429438.

Myers, N., Mittermeier, R.A., Mittermeier, C.G., Da Fonseca, G.A. and Kent, J. (2000) Biodiversity hotspots for conservation priorities. Nature, 403(6772), 853-858. 
Newmaster, S.G., Fazekas, A.J.J. and Ragupathy, S. (2006) DNA barcoding in land plants: Evaluation of $\mathrm{rbcL}$ in a multigene tiered approach. Canadian Journal of Botany, 84(3), 335-341.

Orme, C.D.L., Davies, R.G., Burgess, M., Eigenbrod, F., Pickup, N., Olson, V.A., Webster, A.J., Ding, T.S., Rasmussen, P.C., Ridgely, R.S. and Stattersfield, A.J. (2005) Global hotspots of species richness are not congruent with endemism or threat. Nature, 436(7053), 1016.

Orthia, L.A., Cook, L.G. and Crisp, M.D. (2005) Generic delimitation and phylogenetic uncertainty: An example from a group that has undergone an explosive radiation. Australian Systematic Botany, 18(1), 41-47.

Oxelman, B. and Lide'n, M. (1995) Generic boundaries in the tribe Sileneae (Caryophyllaceae) as inferred from nuclear rDNA sequences. Taxon, 44, 525-542.

Oxelman, B., Lidén, M. and Berglund, D. (1997) Chloroplastrps16 intron phylogeny of the tribe Sileneae (Caryophyllaceae). Plant Systematics and Evolution, 206(1-4), 393-410.

Pirani, A., Zarre, S., Pfeil, B.E., Bertrand, Y.J., Assadi, M. and Oxelman, B. (2014) Molecular phylogeny of Acanthophyllum (Caryophyllaceae: Caryophylleae), with emphasis on infrageneric classification. Taxon, 63(3), 592-607.

Rautenberg, A., Filatov, D., Svennblad, B., Heidari, N. and Oxelman, B. (2008) Conflicting phylogenetic signals in the $\mathrm{SIX} 1 / \mathrm{Y} 1$ gene in Silene. $B M C$ Evolutionary Biology, 8(1), 299.

Sadeghian, S., Zarre, S., Rabeler, R.K. and Heubl, G. (2015) Molecular phylogenetic analysis of Arenaria (Caryophyllaceae: tribe Arenarieae) and its allies

$$
\begin{aligned}
& \text { توثيق ثلاثة أنواع من العائلة القرنفلية متوطنة بشبه جزيرة سيناء باستخدام تقتية الباركود } \\
& \text { كلأحماض النووية تونية }
\end{aligned}
$$

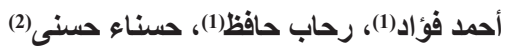

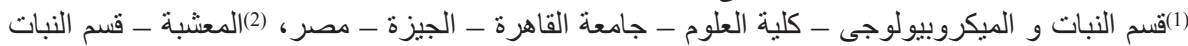

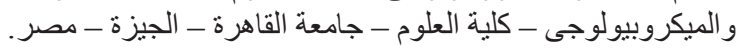

$$
\begin{aligned}
& \text { جاءت الأخرى بسلف مشترك للنو عين الأخرين. }
\end{aligned}
$$

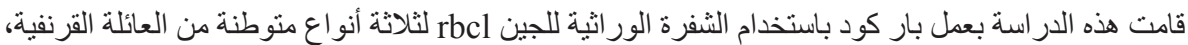

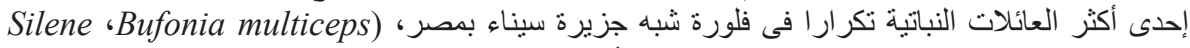
(S. oreosinaica و leucophylla

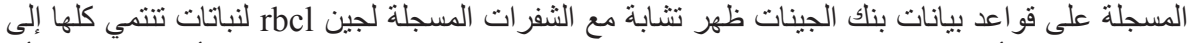

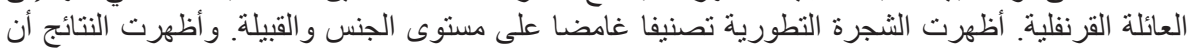
الأنو اع الثلاثة قد استوطنو اشبة الجزيرة على مرحلتين، أسفرت الأولى عن ظهور Silene leucophylla بينما 